\title{
El encanto de Tutankhamón. La egiptomanía en la prensa porteña (1923-1925) ${ }^{1}$
}

\section{The charm of Tutankhamun. Egyptomania in the porteña press (1923-1925)}

\author{
MATÍAS ALDERETE \\ Universidad de Buenos Aires (Argentina) \\ matialderete@outlook.com
}

RESUMEN

El descubrimiento de la tumba de Tutankhamón en los años veinte evidenció la fascinación que la antigüedad egipcia ejerció en el mundo occidental. Argentina no fue la excepción: la prensa porteña se hizo eco de este acontecimiento, que circuló de formas diversas en los periódicos y semanarios ilustrados. Podían verse noticias, artículos de interés, ilustraciones y fotografias que, recurriendo a tópicos de la egiptomanía del Viejo Mundo, exaltaban la sensualidad y el misterio de los tiempos faraónicos. Pero al mismo tiempo, la prensa porteña generó contenido local: acudiendo a relatos, ilustraciones o sátiras políticas evocaron al Antiguo Egipto y lo hicieron más cercano; en este sentido, la egiptomanía funcionó como un vínculo entre la joven nación y el horizonte global, que le permitió comulgar con un sentimiento de encanto cosmopolita.

Palabras clave: egiptomanía; prensa; encantamiento; cosmopolita

ABSTRACT

The Tutankhamen's tomb discovery in the 1920s evidenced the western fascination upon the Ancient Egypt. Argentina wasn't an exception: the Buenos Aires press echoed this event, which was circulated in various ways in illustrated newspapers and weeklies. Readers could follow news, articles of interest, illustrations, and photographs that, taking elements from european Egyptomania, exalted the sensuality and mystery of ancient times. The local press generated its own content: stories, illustrations or political satires evoked pharaonic Egypt and made it closer. That way, Egyptomania functioned as a link between the young nation and the global horizon, allowing it to join with a feeling of cosmopolitan charm.

Keywords: Egyptomania; Press; enchantment; Cosmopolitan.

\footnotetext{
1 El presente trabajo es una versión adaptada de un capítulo de mi tesis de maestría en Historia Contemporánea (UNGS), El encanto orientalista. Representaciones y consumos del Oriente en la prensa porteña de los años veinte (1919-1925). La investigación fue dirigida por la Dra. Paula Bontempo, a quién agradezco todos los comentarios y señalamientos realizados. También quiero agradecer la lectura, los comentarios y las sugerencias realizados por los evaluadores anónimos, que me permitieron clarificar, profundizar y excluir algunos de los temas abordados.
}

Esta obra está sujeta a la Licencia Reconocimiento-NoComercial-CompartirIgual 4.0 Internacional de Creative Commons. http://creativecommons.org/licenses/by-nc-sa/4.0/ 
Dentro de las representaciones sobre el Oriente, el Antiguo Egipto ocupa un lugar relevante. Si bien es cierto, como ha señalado Edward Said (Said, 2002 [1978]), que el discurso orientalista elimina cualquier diferencia local y regional bajo la evocación de un Oriente compacto y homogéneo, el imaginario sobre Egipto funciona como una zona indeterminada o liminal (Fryxell, 2017), siendo el puente que une Oriente y Occidente, Europa y África (Gómez Espelosín y Pérez Largacha, 1997, pp. 11-110). Pensada como una tierra de secretos y sabiduría, Egipto pasó a formar parte de la memoria del Occidente desde tiempos muy prístinos. En este sentido, Jan Assmann (2005) sostiene que Egipto nunca fue descubierto por Occidente, pues nunca desapareció, permaneciendo "presente en los archivos de la memoria cultural de Europa" (pp. 57-58).

Se ha denominado "egiptomanía" a esa fascinación de la cultura occidental sobre Egipto. En contraposición a la egiptología, la disciplina que emprende el estudio científico a partir de la evidencia histórica, la egiptomanía ha sido tomado como una vulgarización del conocimiento, una especie de "museo del malentendido" (Assmann, 2005, p. 57), que tergiversa el estudio académico y riguroso del Egipto faraónico en favor de la exposición de lo inusual, lo mistérico y lo desconocido.

La fascinación por la cultura egipcia ha sido una constante en el gusto europeo desde la antigüedad, pudiéndose ver la influencia egipcianizante en las artes o la arquitectura (Curl, 2005). Se ha señalado que fueron las elites letradas las protagonistas de las diferentes oleadas de egiptomanía hasta el siglo XIX (Fritze, 2016, p. 333), constituyendo un elemento que distinguiría aquellos sectores cultos de los que no lo eran. Pero en los años veinte del siglo XX esta situación se modificaría de forma irreversible a raíz de un nuevo descubrimiento: en noviembre de 1922, el arqueologo británico Howard Carter encuentra un sepulcro intacto que había pertenecido al faraón Tutankhamón. ${ }^{2} \mathrm{El}$ acontecimiento despertó un profundo interés del público europeo en general, haciéndose cotidiana la presencia del Antiguo Egipto, pero esta vez ayudada por la masificación de la prensa, las películas y la fotografia. Retomando tópicos que fueron propios de la egiptomanía en períodos anteriores, las representaciones sobre la antigüedad egipcia que circularon hacian hincapié en el misterio y la fantasía, convergiendo con la sensualidad, el poder de los muertos y una sabiduría ancestral. La aparición de una tumba real con sus suntuosos objetos y la trágica muerte de quién financió la expedición al Valle de los

2Tutankhamón (1322-1322 a.C) es el onceavo faraón de la Dinastía XVIII, hijo del faraón Akhenatón. Mientras Akhenatón rompió relaciones con el poderoso sacerdocio de Amón, mudó la capital a Tell-elAmarna, y declaró el monoteísmo, Tutankhamón fue el soberano que dio los primeros pasos para volver a la ortodoxia, e incluso emprendió cierta política expansionista, especialmente hacia Asia y Nubia. Fallece antes de cumplir veinte años. (San Martín y Serrano, 1998, pp. 312-313, 345).

He decidido seguir la sugerencia de un evaluador y escribiré en el trabajo Tutankhamón y no Tutankamón, que deriva de la transliteración de su nombre en su titulatura real.

\section{anuario.}


Reyes, Lord Carnarvon, fomentaron un renacido interés por el Antiguo Egipto, esta vez denominado tutmania, en especial referencia a Tutankhamón.

Pero esta atracción no fue un monopolio europeo. En este artículo abordaré las representaciones del Antiguo Egipto en la prensa porteña, poniendo el foco en noticias, artículos de interés, imágenes satíricas o relatos cortos que permitieron que el Egipto Antiguo reviva continuamente en las páginas de diarios y revistas de estos años, en la cual se coló lo mágico, asombroso y misterioso.

La relevancia que le otorgo a la prensa para indagar este fenómeno se debe a múltiples factores: por un lado, se erige como vehiculizadora y productora activa de representaciones sociales dirigidas a una amplia franja de lectores, y es que el interés por el Antiguo Egipto no quedó delimitado socialmente, sino que apeló al interés masivo de hombres y mujeres. En segunda instancia, ha sido señalada la importancia de su rol modernizador en el cambio de siglo: desde las últimas décadas del siglo XIX se la visualiza como un elemento central del progreso social, constitutivo de cualquier sociedad cosmopolita. La llegada del cable telegráfico operó en el imaginario local como un magnánimo avance civilizatorio que permitía reducir los tiempos y hacer más porosas las distancias, adentrando a la joven Argentina en el concierto global. Como Lila Caimari (2018) ha señalado, la prensa funcionó como una "superficie de llegada" de aquellas novedades globales que le otorgarian densidad al mundo (pp. 8284). Para los años veinte, los diarios y las revistas ilustradas eran parte de la cotidianeidad de los sujetos urbanos, existiendo una gran variedad de publicaciones con cuantiosas tiradas que permitieron la democratización de la experiencia lectora. ${ }^{3}$

En tanto vínculo con el mundo, sin embargo, es importante no ver a la prensa como una simple receptora de intereses globales. Es cierto que la Buenos Aires en los años veinte ha sido entendida como una "modernidad periférica", en la que coexistían "elementos defensivos y residuales junto a los programas renovadores; rasgos culturales de la formación criolla al mismo tiempo que un proceso descomunal de importación de bienes, discursos y prácticas simbólicas" (Sarlo, 2003 [1988], p. 28). Una lectura de este tipo invita a pensar a la tutmanía como una más de estas importaciones europeas en una sociedad periférica. Pero hay que tener en cuenta aquel señalamiento realizado Victor Goldgel (2013) sobre lo peligroso que puede resultar la mistificación de conceptos como "centro" y "periferia" (pp. 40-41), ya que ambos mantienen una relación lineal, unidireccional y asimétrica; en este marco, la

\footnotetext{
3 En este aspecto, el presente trabajo sigue los lineamientos que han sido vislumbrados en trabajos como los de Sylvia Saitta (1998) y Paula Bontempo (2012). Mientras Saitta ha indagado como el diario Crítica construyó un pacto de lectura con sus lectores a partir de un análisis estructural del periódico, Bontempo ha desmenuzado la producción editorial de Atlántida, dando cuenta cómo se conformaron productos que configuran sujetos diferenciados. Sobre la relevancia de la prensa masiva en los años veinte, puede consultarse Sarlo (2011 [1985]); Saitta, (1998, 2000); Bontempo (2012); y Rogers (2014). Sobre el impacto de la prensa en tanto artefacto modernizador, Caimari $(2015,2018)$.
} 
circulación transnacional de valores, ideas e imaginarios puede verse como un simple proceso de duplicación o deformación de un fenómeno "original" proveniente de un centro, transformando a las sociedades periféricas en destinatarias pasivas inmersas en falsas modernidades.

Allegra Fryxell (2017) ha sugerido que la tutmanía exhibió al público británico de entreguerra aquel pasado egipcio como parte de un tiempo inmemorial, seductor y misterioso por partes iguales, siendo el Egipto faraónico un elemento que "encanta" el mundo moderno a partir de deseos y fantasías. ${ }^{4}$ Entonces, ¿cómo impactó la tutmanía en una ciudad como Buenos Aires? ¿La prensa porteña simplemente reproducia las nociones europeas sobre Egipto? ¿ $O$ también fue seducida por la tutmanía? Partiendo de estas interpelaciones, busco indagar el imaginario del Antiguo Egipto que se construyó en la prensa porteña a partir del descubrimiento de la tumba de Tutankhamón. Estimo que explorar este fenómeno será una contribución desde la producción historiográfica a los estudios sobre los orientalismos latinoaméricanos en general y sobre la egiptomanía en especial. ${ }^{5}$ En tanto fenómeno social, la egiptomania ha sido intensamente estudiada; ${ }^{6}$ no obstante, ha despertado

\footnotetext{
4 Fryxell retoma el concepto de "encantamiento de la modernidad" como lo entiende Michael Saler (2006, 2012; Saler y Landy, 2009), que discute la extendida concepción de modernidad como un espacio de desencantamiento y progresiva individuación y racionalización. En vez de ponderar la pérdida del poder de la magia en las sociedades modernas, Saler sugiere que se producen continuamente estrategias de encantamiento secular que expresan anhelos, deseos y ansiedades sociales.

Los tópicos de encantamiento no son ajenos a esta ciudad que había experimentado, en el correr de unas décadas, un enorme crecimiento poblacional a raíz de una importante migración, una alfabetización masiva y un crecimiento económico vertiginoso Beatriz Sarlo (1997 [1992]) ya había señalado el tópico del encantamiento en la fuerza de la fantasía técnica del hombre moderno, que ve todo posible y verosimil; más recientemente Soledad Quereilhac (2016) ha investigado las fantasias que despertaba la ciencia de entresiglo y las permeables fronteras entre la racionalidad y lo oculto e insondable.

5 Una definición clásica del orientalismo se encuentra vinculada a la obra pionera de Edward Said (2002 [1978]), en tanto discurso que genera concepción occidental que define, estudia y tipifica el 'Oriente' como un espacio-tiempo antagónico a Occidente, anclando su estudio a las metrópolis imperiales del siglo XIX. Las investigaciones sobre los orientalismos latinoamericanos han sido lo realmente fructiferos en la crítica literaria (Altamirano,1994; Tinajero, 2003; Nagy Zekmi, 2006, y 2008; Jardines del Cueto, 2016), aunque no fue así en otras disciplinas. Por ejemplo, las producciones vinculadas a la historiografia han sido menos exploradas, a pesar de la existencia de trabajos como los de Hernán Taboada (1998), de los primeros en proponer la existencia de un "orientalismo periférico", vinculado a la recepción y circulación del orientalismo europeizado en los sectores intelectuales criollos. Esta situación probablemente pueda servir como un indicador de la importancia de los enfoques transdisciplinarios para analizar estos fenómenos, como así lo demuestran trabajos recientes como los de Axel Gasquet $(2007,2015)$ y Martín Bergel (2015).

${ }^{6}$ La producción sobre la egiptomanía es realmente extensa, siendo los casos más estudiados los de las historiografias anglosajonas, especialmente abocadas a analizar los fenómenos estadounidense e inglés. Lamentablemente, no se le ha dedicado el mismo interés en la historiografia latinoamericana, a excepción del caso brasileño que cuenta con una asidua producción Es necesario resaltar el trabajo de Margaret Bakos (2004), una compilación que indaga en las apropiaciones de la antigüedad egipcia en diferentes contextos de la historia brasileña. Un extenso y minucioso estado de la cuestión fue realizado por Bakos, Santos, Coelho y da Silva (2012).
}

\section{anuario.}


escaso interés en la historiografia argentina, siendo entendida como

un afán europeísta de ciertos sectores sociales encumbrados o como un fetichismo simbólico de la masonería (Méndez y Belej, 2012; Míguez, Malerba y Flores, 2015), aunque recientemente se ha rechazado que las representaciones vernáculas sobre el Antiguo Egipto sean simples repeticiones de las europeas: en su análisis de los diarios de viaje de la elite rioplantese de fines del siglo XIX, Leila Salem (2018) advierte como se tensionan los tópicos clásicos europeos, dando espacio a imágenes más flexibles y hasta menos condenatorias. ${ }^{7}$

Retomando lineamientos esbozados por Martín Bergel (2015) en su análisis sobre el orientalismo argentino,$^{8}$ presumo que el abordaje de la prensa masiva permitirá dar cuenta de la circulación social de la tutmanía y de la manera en la cual se hicieron presentes diferentes representaciones sobre en Antiguo Egipto. ${ }^{9}$ Diarios y revistas hicieron confluir tópicos globales y locales en la figura de Tutankhamón: si la "maldición de la momia" y un sugerente universo místico fueron aspectos recurrentemente recuperados, también hubo una producción de contenido vernáculo y que hará referencia a la actualidad nacional y, en especial, porteña.

A partir del relevamiento de fuentes, esta investigación se centrará en el período que va desde 1923 hasta 1925. La periodización propuesta coincide con el descubrimiento de la tumba de Tutankhamón: el acontecimiento data de los últimos dias de noviembre de 1922, mientras que la prensa local empezará a interesarse en el tema desde enero de 1923. Hasta 1925, podría decirse que casi cada semana hay alguna referencia al faraón o a la cultura egipcia, no solamente en noticias vinculadas a la excavación de la tumba, sino también en artículos de interés, coberturas exclusivas, sátiras y chistes misceláneos. Por otro lado, estos son momento de algidez política en el partido gobernante: en efecto, la alternancia presidencial dentro de la Unión Cívica Radical generó fricciones que fueron expuestas públicamente, y la figura

\footnotetext{
7 También puede nombrarse la investigación de Dante Peralta (2016), si bien no se enfoca en la egiptomanía, resalta el interés de la prensa de los años veinte por el descubrimiento de la tumba de Tutankhamón, aunque relacionado con el interés del discurso científico en general y de la arqueología en particular.

8 La obra de Bergel (2015) es actualmente la investigación con mayor proyección historiográfica. Su hipótesis central sugiere que el impacto de la guerra trastoca las nociones sobre el Oriente que dominaron durante la segunda mitad del siglo XIX: si el afán eurocéntrico de la intelectualidad argentina fomentó una visión del Oriente vinculada al salvajismo y la barbarie, tópicos comunes en el orientalismo europeo, la Primera Guerra Mundial socavará los fundamentos del mundo occidental, permitiendo la emergencia de un discurso que él llamará orientalismo invertido, en tanto fuerte resquebrajamiento de la influencia europea y una nueva ponderación superlativa sobre el Oriente. Desde su perspectiva, la prensa desde finales del siglo XIX permitió expandir la visión orientalista predominante negativa, al insertar al Oriente en una "imaginación geográfica-cultural" más amplia y dinámica (p. 94).

9 Para el caso español, Esther Pons Mellado (1999) también ha puesto en relieve el rol de la prensa en su análisis de la cobertura periodística a la visita de Carter a Madrid hacia fines de 1924.
}

\section{anuario.}


de Tutankhamón es utilizada para hacer continuas referencias a la disputa entre Marcelo de Alvear e Hipólito Yrigoyen, presidente y expresidente de la Argentina. La focalización en este período permitirá analizar la configuración de una egiptomanía vernácula en la cual los tópicos europeos se mixturan con los propuestos por la prensa porteña.

Las publicaciones seleccionadas cubren un amplio espectro, tanto temático como de público, compartiendo ciertas similitudes, aunque también con marcadas diferencias. Con respecto a semanarios ilustrados, son centrales Caras y Caretas, El Hogar, Para Ti y Atlántida; con respecto a la prensa periódica, he privilegiado Crítica y La Nación, por sus estilos casi antagónicos y sus públicos diferenciados (Saitta, 2000). Prestare especial atención a la relación entre texto e imagen: la relevancia de la cultura visual en la prensa masiva ha sido ya señalada en otras investigaciones que no las ven como simples ilustradoras de lo escrito, sino que conciben a la prensa de principio de siglo como una amalgama indisociable de texto e iconografia otorgando especial atención a los aspectos performativos de la imagen. ${ }^{10}$

El trabajo se divide en cuatro apartados más una introducción y una conclusión. En primera instancia, a partir del relato de la apertura de la tumba de Tutankhamón por parte de Howard Carter y Lord Carnarvon, examinaré diferentes claves teóricas e históricas para entender el fenómeno en su contexto europeo; en segunda instancia, analizare la cobertura en los medios de prensa locales sobre el fenómeno, indagando sobre el material escrito y el rol de las ilustraciones, central en la constitución de un imaginario de la antigüedad egipcia al presentar a la tumba de Tutankhamón como un espacio milenario y secreto; sobre este aspecto, en el tercer apartado me adentraré en dos relatos escritos por Leopoldo Lugones, influidos fuertemente por la tutmanía, que serán publicados en La Nación en 1923 y luego reunidos en su libro Cuentos fatales. Finalmente, en el último apartado analizare la convergencia de la tutmanía con la sátira, en especial con el humor político y las referencias a la interna del partido gobernante, propiciando un uso político de los motivos egiptomaníacos.

\section{Reviviendo la magia egipcia: la tumba de Tutankhamón.}

Hacia mediados de la década de 1920, en las páginas de cualquier medio periodístico se podía encontrar referencias de uno de los acontecimientos más populares de la historia de la arqueología: el descubrimiento de la tumba de Tutankhamón. Tres fueron los protagonistas de este suceso importantísimo el egiptólogo Howard Carter, el profesional a cargo del trabajo; su mecenas, George Edward Herbert, Conde de

\footnotetext{
10 Esta es la línea de trabajos como los Sandra Szir (2011) y Julia Ariza (2017), o las compilaciones de Marcela Gené y Laura Malosetti Costa (2009), o de Gené y Szir (2018). Retomaré especialmente la propuesta de Louis Marin (2009), que entiende a las imágenes con una capacidad de potencia creadora, cuya capacidad representacional subvierte el orden entre la imagen y su referente.
}

\section{anuario.}


Carnarvon, mejor conocido como Lord Carnarvon; y finalmente Tutankhamón, un antiguo faraón cuyo cuerpo momificado transportó al Antiguo Egipto a la sociedad de masas del siglo XX.

Desde 1917, Carter emprendió diversas excavaciones en el Valle de los Reyes. El arduo trabajo fue financiado por Lord Carnarvon, un aristócrata inglés apasionado del mundo antiguo y en especial del Egipto faraónico, que obtuvo permisos del gobierno egipcio para excavar la zona. Hasta 1922 las excavaciones arrojaron magros resultados y Carnarvon estaba realmente decepcionado, hasta que fines de ese año Carter tuvo la suerte de su lado: el 4 de noviembre de 1922 encontró indicios de una posible escalera sepultada por bancos rocosos, que lo llevaron a una puerta con un sello en el cuál podía leer el nombre del faraón, Tutankhamón. Carter comunicó prontamente la situación a su mecenas, y Carnarvon llegó a Luxor el 23 de noviembre. Tres días después abrieron la tumba, en la cual encontraron, en palabras de Carter, "cosas maravillosas" (Carter y Mace, 1963, I pp. 94-96; Fritze, 2016, p. 311).

Pronto el acontecimiento llegó a la prensa: el magazine inglés The Times le dedicó especial atención al "descubrimiento más sensacional de la egiptología de este siglo" (Luckhurst, 2012, p. 6). Eventualmente, este magazine fue el medio periodístico con el cual Carnarvon firmó un contrato de exclusividad hacia principios de 1923, otorgando el monopolio desde ese momento sobre el trabajo fotográfico y académico sobre Tutankhamón.

La exclusividad de The Times dejó en una situación de desventaja a otros periódicos, que lograron subsanar el hecho a partir de un acontecimiento fortuito y trágico: la muerte de Carnarvon. El aristócrata inglés fue picado por un mosquito en una de sus mejillas, herida que se magnificó al momento de rasurarse y más tarde se infectó. El inesperado accidente doméstico continuó dramáticamente: Carnarvon primero pasa algunos días con fiebre y finalmente, cuando parecía recuperarse, se enferma con una potente neumonía, falleciendo en El Cairo el 5 de abril. En sus páginas, el Daily Express, uno de los medios de prensa excluidos en el contrato de exclusividad, contó como el hotel donde se alojaba Carnarvon quedó a oscuras en el momento exacto de su muerte, signo que puede ser interpretado como un "mal augurio" (Luckhurst, 2012 , p. 9). De esta forma, la "maldición de la momia" se cobró una víctima respetable y públicamente conocida: evidentemente no podía pasar desapercibida.

La revelación de la tumba de Tutankhamón permitió explotar uno de los principales tópicos que la arqueología ha llevado consigo desde sus inicios: la idea de experiencia o descubrimiento que, en tanto algo novedoso, se presenta como el artífice de la develación de un secreto que de otra forma permanecería en la oscuridad (Joyce, 2002). Empero, reducir la tutmanía al fetichismo del descubrimiento resulta una 
explicación insuficiente, ya que deja de lado otros elementos sobre los cuales Egipto volverá a hacerse presente en la imaginación occidental.

Es posible señalar tres aspectos centrales en los cuales la tutmanía pudo proyectarse para transformarse en un fenómeno de masas. Un primer elemento se encuentra relacionado con el consumo conspicuo del Antiguo Egipto. Ya desde el Renacimiento el polvo de momia se volvió codiciado debido a sus supuestas propiedades curativas: Catalina de Medici en 1549 organizó una expedición a Saqqara para recolectar momias que serian usadas en diferentes preparaciones medicinales. El comercio de este producto floreció en el siglo XVI, incluso apareciendo falsificaciones. Posteriormente, debido a su "inherente espectacularidad", la presencia de momias fue bastante común en las colecciones privadas de los aristócratas, hasta que finalmente los científicos de los siglos XVII y XVIII empiezan a estudiarlas para comprender el proceso de momificación (Moshenka, 2013, pp. 4-8). La llegada de Napoleón a Egipto hacia fines del siglo XVIII acentuó este interés, mientras diversos artefactos egipcios que fueron llevados a Europa se transformaron en mercancías de lujo y grandilocuencia. Parte de estas se expusieron públicamente para forjar un imaginario épico e imperial del legado napoleónico, erigiendo fuentes de agua para conmemorar su Campaña Egipcia y obeliscos para recordar sus victorias sobre Prusia y Polonia (Parramore, 2011, p. 200). Mientras tanto, los sectores letrados ingleses también buscaron considerarse "herederos legítimos" de la cultura egipcia, diseñando edificios con influencias egipcianizantes y decorando habitaciones enteras con objetos saqueados de tumbas o pinturas románticas que hacian referencia a los monumentos faraónicos. Medio siglo más tarde todavía podía encontrarse rastros de este tipo de cultura del consumo exótico y suntuoso: en muchas reuniones sociales se invitaban a personalidades a tomar el té y abrir momias, incluso frente un gran público que ovacionaba cuando se mostraba un pie arrugado y ennegrecido (Gómez Espelosín y Pérez Largacha, 1997, pp. 181-182). El más conocido fue Thomas Pettigrew, un anticuario que organizaba verdaderas ceremonias antes de desenrollar la momia de turno.

Un segundo aspecto a tener en cuenta está relacionado con las formas en las cuales el Antiguo Egipto circuló en las publicaciones. El reencuentro de Europa con Egipto gracias a las campañas napoleónicas permitió la edición de una obra monumental y colectiva, de la cual participaron aproximadamente 160 investigadores y 400 artistas: Description de l'Égypte, serializada en 23 volúmenes entre 1809 y 1829. Andrew Wheatcroft (2003) señala que este trabajo inaugura una forma de apropiación del Egipto Antiguo, en la cual se establece una fuerte interdependencia entre la palabra escrita y la utilización de imágenes. ${ }^{11}$ Teniendo en cuenta el tamaño y gramaje de las

11 Si bien la afirmación de Wheatcroft se vincula al proceso de democratización de la cultura visual del Antiguo Egipto entre los siglos XIX y XX a partir de los temas esotéricos, es importante señalar que desde el siglo XVI hay un interés profundo en la antigüedad egipcia en la que la palabra escrita viene acompañada por ilustraciones. Siguiendo el planteo de Assmann (2005), fueron el Renacimiento y los siglos XVI y XVII los principales momentos de reapertura egiptomaníaca, con importantes dosis de 
hojas, los costos de producción de este tipo de publicaciones eran astronómicos, siendo solamente accesibles a un selecto grupo de compradores. Las mejoras técnicas eventualmente permitieron modificar los formatos lujosos, introduciéndose las ediciones baratas, que coparian las tiendas de libros. Sin embargo, la preponderancia de la imagen no desapareció de los diversos tipos de publicaciones sobre el Antiguo Egipto. Así, se podía visualizar un mundo antiguo y extraño a partir de ciertos elementos que se transformaron en prototípicos: edificios monumentales, artefactos misteriosos, desiertos sin límites y rostros faraónicos poblaron la imaginación europea, generando un "arquetipo" de lo egipcio que pervive hasta nuestros días (Rice y MacDonald, 2003).

La figura de la momia como un ente abyecto y amenazante es el tercer elemento que le otorgó carnadura a la tutmanía. En tanto figura espectral, la momia posee marcas de monstruosidad en su especificidad histórica. En efecto, el monstruo representa ansiedad y la marginalidad o el bordeo de las fronteras; se escapa de lo cognoscible y está siempre en puerta de la diferencia, ya que son un "otro" profundo en el cual se arraiga en imaginario social. Pero a su vez representan un deseo subterráneo de la sociedad que lo crea (Cohen, 1996). En este sentido, Roger Luckhurst (2012) indica que Tutankhamón cataliza diferentes ansiedades decimonónicas, que se encuentran relacionadas no solamente con la necesidad del asombro y la maravilla perdidas en la modernidad, sino con el temor a la muerte, la persecución de los vivos de parte de fantasmas y los maleficios; así, el mismísimo Arthur Conan Doyle aseguraba en la década de 1920 que la muerte de Lord Carnarvon se debió a las fuerzas del mal (Luckhurst, 2012, p. 10; Fritze, 2016, p. 320). En la figura de la momia conviven la idea de la víctima del mundo moderno, el tabú de la burla a la muerte, la sensualidad y erotismo de lo desconocido y misterioso, y la malevolencia del mundo de los espíritus (Day, 2006). Como se analizará, en la tutmanía podrán verse las críticas en un marcado tono sensacionalista al tabú occidental de la profanación de tumbas,

fascinación y misterio, pues durante la Edad Media el lugar de Egipto fue marginal (pp. 58-59). En este contexto, las traducciones del Corpus Hermeticum de Hermes Trimegisto, o de Hieroglyphica de Horapollo interesaron a los humanistas renacentistas al ser elementos que asediaban el discurso científico y religioso preconcebido. El descubrimiento de la tabla isíaca, Mensa Isiaca, una placa de cobre que data del siglo I y que muchos especularon que era una llave que permitiría conocer los secretos de la religiosidad y escritura egipcia, profundizó la egiptomanía renacentista y dio pie a la proliferación de ilustraciones que emulaban sus motivos pictóricos, como Hypnerotomachia Thesaurus Hieroglyphicorum (1608) de Herwart von Hohenburg. El ejemplo más relevante de la fascinación que despertó este artefacto probablemente sea la obra central de Athanasius Kircher Oedipus Aegyptiacus, cuyos tres volúmenes fueron publicados entre 1652 y 1654. La tabla isíaca era, según Kircher, una representación del orden cósmico que incluso podría ayudar a revelar los orígenes de las religiones. También proclamó haber descifrado la escritura jeroglífica, a pesar que eventualmente se descubrió que los signos grabados en la placa no eran nada más que motivos decorativos. Véase Assmann (2005); Curl (2005, pp. 43-226); y Gómez Espelosín y Pérez Largacha (1997, pp. 126-131)

\section{anuario.}




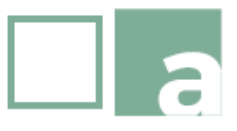

mixturadas con la celebración y espectacularización del exotismo y secretismo egipcio.

Podría decirse que la egiptomanía se fue eventualmente democratizando. Egipto, evocado desde una forma poderosamente visual, terminó configurando cierto imaginario que redundaba en las ruinas arquitectónicas y el misticismo de esta civilización. A la par, la figura de la momia conjugó una variedad de tópicos, de deseos y hasta de tabúes occidentales, que la transformaron en un ente que, en vez de hacer referencia a los antiguos egipcios, hablaba más de las ansiedades europeas. La llegada de Tutankhamón al siglo XX potenció y coaligó todos estos aspectos.

\section{Tutankhamón en las noticias porteñas}

La figura de Tutankhamón empieza a hacerse presente desde inicios de 1923, cuando la noticia cobra relevancia local y La Nación publica una detallada nota sintetizando los datos recibidos a través de cables desde diciembre de 1922, informando sobre "una serie de descubrimientos arqueológicos" de enorme trascendencia. El artículo resumía la historia canónica comentada en la prensa británica, incluyendo pintorescos datos sobre el reinado de Tutankhamón e imágenes que no hacían real referencia al descubrimiento aludido, aunque si al Egipto Antiguo: murales decorados $^{12}$ permitían visualizar la vida de los antiguos habitantes de Egipto, mientras un panorama del desértico Valle de los Reyes y objetos lujosos trataban de situar el descubrimiento en este foráneo mundo antiguo ${ }^{13}$ (fig. 1). La presencia de imágenes para llamar la atención del lector es digna de mención, especialmente debido a la escasa presencia visual en el diario: La Nación era lo que se llamaba "prensa seria" (Saitta, 2000), donde los extensos artículos sobre la política argentina se entremezclaban con la política internacional. Las primeras dos o tres páginas de cada edición estaban dedicadas a diferentes acontecimientos de relevancia global a partir de cables telegráficos distribuidos por diferentes agencias, y fue en este apartado donde se cubrió el descubrimiento de la tumba de Tutankhamón.

\footnotetext{
12 El mural en cuestión corresponde al sepulcro de Nakht, un funcionario estatal durante el gobierno de Tutmosis III.

13 El descubrimiento de Lord Carnarvon en el Valle del Nilo, La Nación, 14/1/1923.
} 


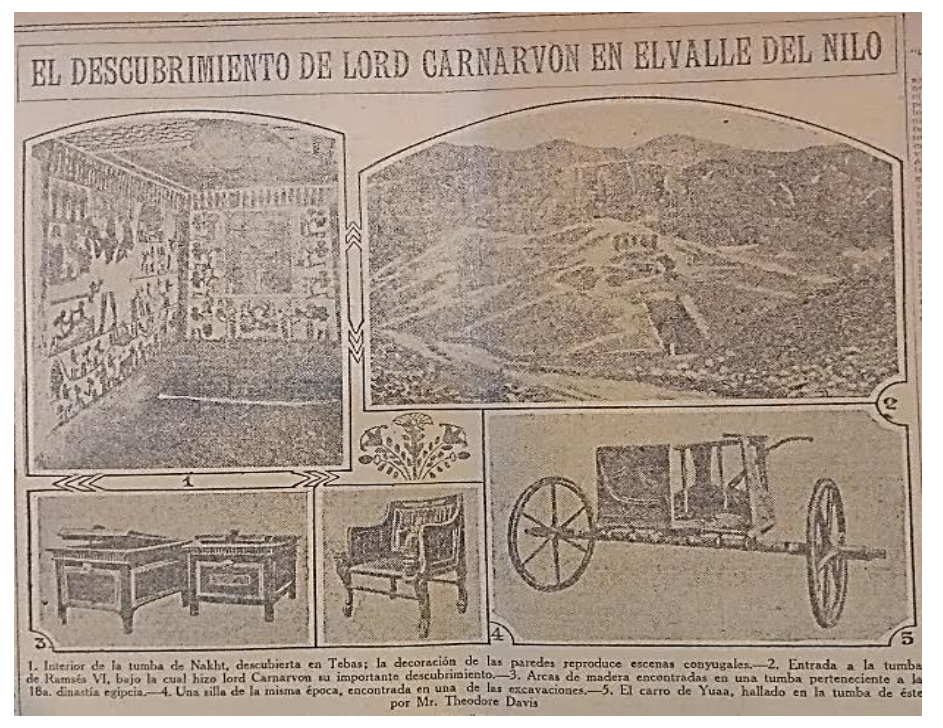

Fig. 1. El descubrimiento de Lord Carnarvon en el Valle del Nilo, La Nación, 14/1/1923. Biblioteca Nacional Mariano Moreno.

El solemne artículo de La Nación fue muy diferente al mostrado más tarde en las páginas de Crítica. Este diario decidió presentar la información con un breve texto en la cual se comentaba la magnificencia del hallazgo, reemplazando las ilustraciones por fotografias de objetos que permitian visualizar el Antiguo Egipto a los lectores de forma realista: sillas imperiales, un carro real o una vasija de alabastro daban cuenta tanto de la suntuosidad de este lejano mundo como también de la jerarquía del descubrimiento. ${ }^{14}$ Tanto fotografias como ilustraciones serán utilizadas de manera continua y mixturada en la cobertura de este acontecimiento por parte de Crítica, jerarquizando la visualidad por sobre la palabra escrita.

Las imágenes buscaron revivir el emocionante momento de la apertura de la tumba, pero también brindaron a los lectores instantáneas de una lujosa antigüedad y del misterioso sepulcro. Ilustraciones oscurantistas en la que sobresalen objetos mortuorios permitieron adentrarse en la "sombría cámara" en la que "no penetró pie humano en treinta siglos" y contemplar "una belleza y emoción incomparable", estableciendo una romantización al Antiguo Egipto. ${ }^{15}$ Tutankhamón es, al mismo tiempo que una presencia primigenia que despierta de su letargo en un mundo moderno, un espectáculo que manifiesta la belleza oriental.

Crítica sostuvo un real interés en Tutankhamón y sus artículos combinaron los secretos de la muerte, los lujosos tesoros, la monumentalidad de las esculturas y la

\footnotetext{
14 Los nuevos descubrimientos arqueológicos en Egipto, Crítica, 16/1/1923.

15 El más emocionante momento de un arqueólogo, Crítica, 19/1/1923.
}

\section{anuario.}




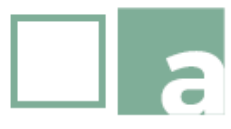

regencia faraónica. ${ }^{16}$ En sus páginas, el faraón fue presentado como un imponente rey y aguerrido guerrero, construyendo su figura alrededor de los tópicos de poder, riqueza y misterio. Incluso se permite realizar una leve insinuación sensual sobre el faraón: una niña porteña de once años es presentada como "la esposa del faraón" (fig. 2), ya que tiene un rostro "singularmente atractivo e interesante y rasgos semitas pronunciados". ${ }^{17}$ La fotografia de esta niña admite pensar de tres aspectos: en primera instancia, el artículo señala que la instantánea fue enviada a la redacción con ese título, siendo un posible indicativo que desde febrero de 1923 el tema despertaba el interés de los lectores y que tenía cierta circulación. En segunda instancia, su publicación por parte de Crítica muestra que, aunque es un fenómeno global, la prensa local intenta filiarse al impacto internacional a partir de la elaboración de cierto contenido original y no limitándose a reproducir cables extranjeros, como hizo en mayor medida La Nación. Finalmente, la aparición de una supuesta bella esposa de Tutankhamón se condice con otras representaciones que, en vez de visualizar al antiguo faraón egipcio como una fútil momia, se lo muestra como una figura envuelta en poder, misterio y lujo: así, una ilustración mostraba un Tutankhamón guerrero, acompañado de un león adiestrado que "causaba un destrozo terrible y pánico entre los enemigos, pues abría el camino al carro del monarca"18 (fig. 3), equiparando el poder del faraón con el agresivo y poderoso felino.

La cobertura sensacionalista de Crítica también mostró al Museo del Cairo, lugar en donde, probablemente, la momia de Tutankhamón se convertirá en "objeto de museo" para satisfacer las ansiedades turistas. ${ }^{19}$ Esta nota marca un provisorio fin a la primera cobertura de noticias en la narración que Crítica fue construyendo desde enero de 1923, que se inició con el descubrimiento y la circulación de la noticia al público en el primer artículo; continuó con una exposición del misterio y la solemnidad del sepulcro, y con la eventual liberación de Tutankhamón de la oscuridad del encierro; exhibió los tesoros de la tumba o hasta la vida cotidiana del faraón en diversas ilustraciones y fotografias; y finalmente, concluyó el recorrido, tanto de Tutankhamón como de la noticia, en el lugar donde el cuerpo momificado descansará por siempre como parte del legado simbólico y material de la humanidad.

\footnotetext{
16 Tutankhamen sale a la luz Crítica, 19/1/1923; Los tesoros de Tutankhamen, Crítica, 20/2/1923; E1 guardián de la tumba de Tutankhamen, Crítica, 22/2/1923; Tutankhamen guardándose a sí mismo, Crítica, 7/3/1923; Una escena de hace treinta y dos siglos, Crítica, 8/3/1923; En la tumba de Tutankhamen, Crítica, 27/3/1923.

17 La esposa de Tutankhamon... en Buenos Aires, Critica, 28/2/1923.

18 Como peleaba Tutankhamen en sus batallas, Crítica, 1/4/1923.

19 El último refugio de Tutankhamon, Crítica, 5/4/1923.
}

\section{anuario.}




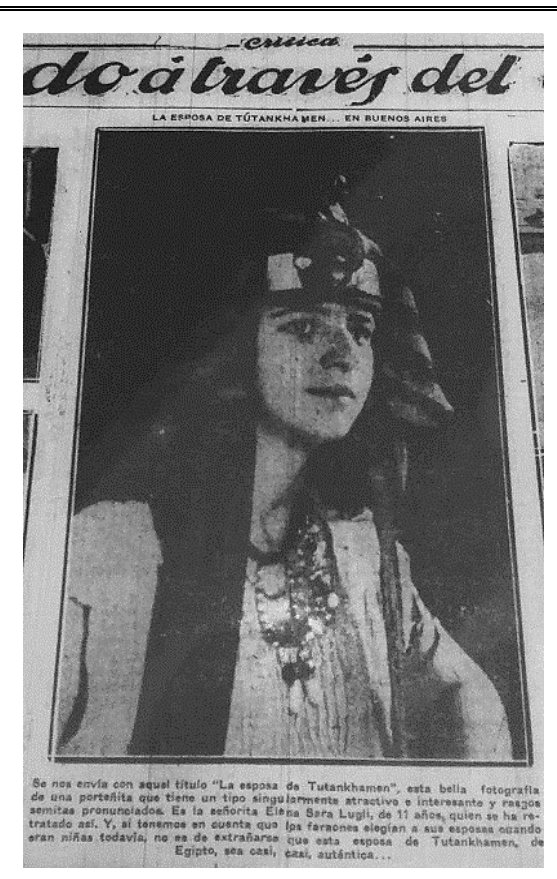

Fig. 2. La esposa de Tutankhamen... en Buenos Aires, Critica, 28/2/1923. Biblioteca Nacional Mariano Moreno.

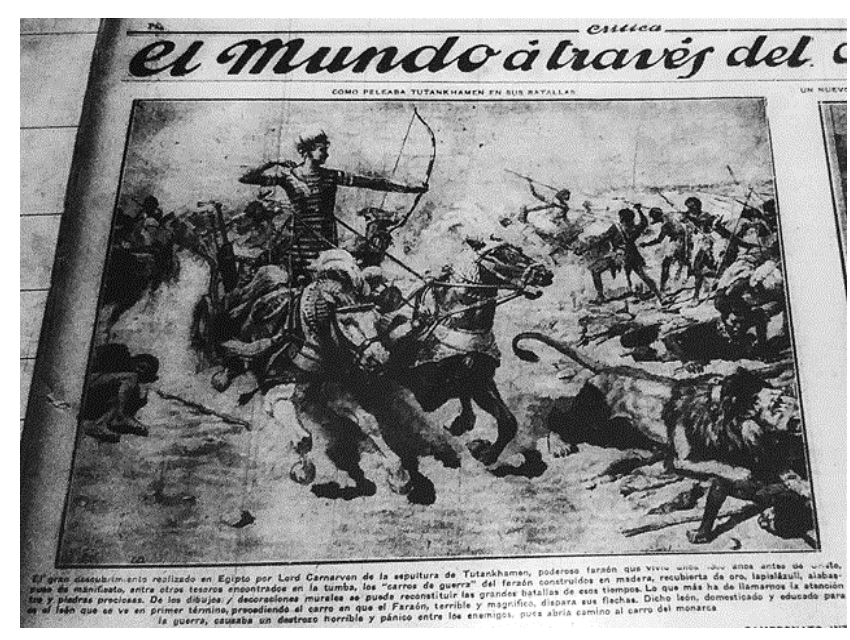

Fig. 3. Como peleaba Tutankhamen en sus batallas, Critica, 1/4/1923. Biblioteca Nacional Mariano Moreno

Las diferencias con La Nación son visibles, cuya cobertura será mucho más sobria y menos monumental, simplemente dedicando algunos cables durante los próximos meses, modus operandi que continuaría durante el verano de 1924.20 Las notas van a ser cortas y apenas reproducirán la información brindada por la agencia de noticias norteamericana Associated Press y, en menor medida, la francesa Havas: para estos años, las agencias norteamericanas habian desembarcado y ofrecían exitosamente sus servicios telegráficos (Sánchez, 2014, pp. 289-294). Sí le dedicó, por otro lado, en los suplementos de variedades de los domingos algunos artículos en dónde se mostraron lujosos objetos egipcios. A pesar de que su cobertura fue menos espectacular que en Crítica, lo cierto es que ni siquiera La Nación quería quedarse por fuera de este fenómeno global, pudiendo verse en sus deslucidas páginas fotografias

20 Por ejemplo, Próximo viaje de la reina de Bélgica a Egipto, La Nación, 5/2/1923; Ha sido abierto ayer el sepulcro de Tutankhamon, La Nación, 16/2/1923; Fue cerrada la Tumba de Tutankhamón, La Nación, 26/2/1923; En la tumba de Tutankhamon, La Nación, 13/1/1924; El día 12 será abierto el sarcófago de Tutankhamon, La Nación, 9/2/1924; Fue abierto el sarcófago de Tutankhamon. La Nación, 13/2/1924; Mr. Carter pretende la mitad de los tesoros descubiertos en Luxor, La Nación, 15/2/1924; El incidente de la tumba de Tutankhamon, La Nación, 17/2/1924; El sepulcro de Tutankhamon La Nación, 20/2/1924.

\section{anuario.}




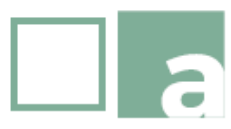

de máscaras $\overline{\text { de oro o de vasijas ornamentadas que irrumpian en el estilo formal del }}$ diario. $^{21}$

La mixtura de fotografias e ilustraciones fue replicada por los semanarios ilustrados, aunque con una carga visual más densa aún. Es mayormente en los magazines donde la tutmanía acude a las representaciones suntuosas y con carga sensual. El Hogar y Atlántida le dedicaron especial atención en las páginas fotográficas, en las cuales incluso Carnarvon, Carter y el mismísimo Tutankhamón aparecerán como personajes del momento. ${ }^{22}$ El faraón permitió conectar al mundo porteño con la cultura cosmopolita: los artículos señalaban que hizo resurgir "en pleno siglo XX aquella admirable civilización egipcia, con su arte, su ciencia, sus ritos, sus misterios" 23 en muchas ciudades europeas. La tutmanía fue relevante en función de mostrarse como una ventana al mundo occidental.

Los semanarios ilustrados utilizarán todo el poder visual para mostrar las enormes estatuas de Tutankhamón, los pequeños sarcófagos de animales y hasta ilustraciones extranjeras de los peculiares rituales funerarios. Las cualidades comunicativas de la imagen materializaron un ostentoso Egipto, generalmente acompañada de muy pocos o breves textos, y mostrando la majestuosidad de los productos encontrados dentro de la tumba. Así, los contenidos propuestos por los semanarios no hacian un detallado seguimiento del descubrimiento, sino que buscaba interesar de muchas formas diferentes. Desde notas de opinión, artículos misceláneos, chistes y divertimentos hasta un concurso de colorear para niños cuyo premio era de 100 pesos para aquellos con "más condiciones artísticas"24 (fig. 4): en todos lados podía verse la presencia de Tutankhamón, que "actualmente está de moda hasta en los vestidos femeninos". 25 Incluso en 1924 Caras y Caretas proclamó orgullosamente la publicación de las noticias y las fotografias oficiales que el magazine británico The Times mostraba en sus páginas, anunciando que esta iniciativa tiene "carácter exclusivo en América del Sur" y mostrando material hasta ese momento muy dificil de acceder a la mayoría del público porteño. ${ }^{26}$ Esta vez las ilustraciones pasaban a un segundo plano y ganaba hegemonía la fotografia, simbolo de la modernidad que permite acercar de forma magnánima al mundo egipcio.

\footnotetext{
21 Por ejemplo, Apuntes de un viaje de turismo por Egipto, La Nación, 20/1/1924.

22 Figuras del momento, El Hogar, 9/3/1923

23 La moda de Tutankhamón, El Hogar, 27/4/1923.

24 Tesoros ocultos, Caras y Caretas, 31/3/1923; Actualidades, Caras y Caretas, 21/4/1923; Concurso infantil, Caras y Caretas, 5/5/1923; Las bodas en Egipto, El Hogar, 11/5/1923; Los jeroglíficos egipcios, El Hogar, 1/6/1923; El origen de nuestras letras, El Hogar, 22/6/1923.

25 Kuniaton, Caras y Caretas, 9/5/1923.

26 Tutankhamon's Tomb, Caras y Caretas, 12/1/1924.
} 


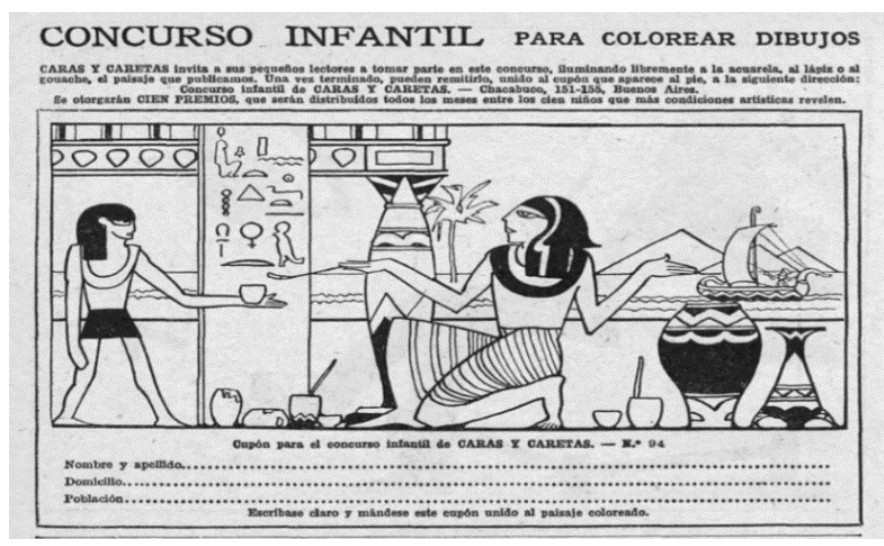

Fig. 4. Concurso infantil. Caras y Caretas, 5/5/1923. Biblioteca Nacional Mariano Moreno.

La tutmanía explotó el tópico sensual del orientalismo. Tanto Crítica como Atlántida y El Hogar ${ }^{27}$ eligieron una imagen en la cual se representa el ritual funerario del faraón, en la cual se puede observar la congoja y exaltación del momento. Sensuales cortesanas podían verse cerca del sarcófago real, en cuyo lamento también podrá advertirse cierto erotismo: presentadas con escasa vestimenta, incluso con el pecho desnudo, una de ellas extendía su mano, mientras otra apretaba su seno; otra cortesana incluso se encontraba en una sugerente pose, arrodillada ante el imponente y erguido ataúd (fig. 5).

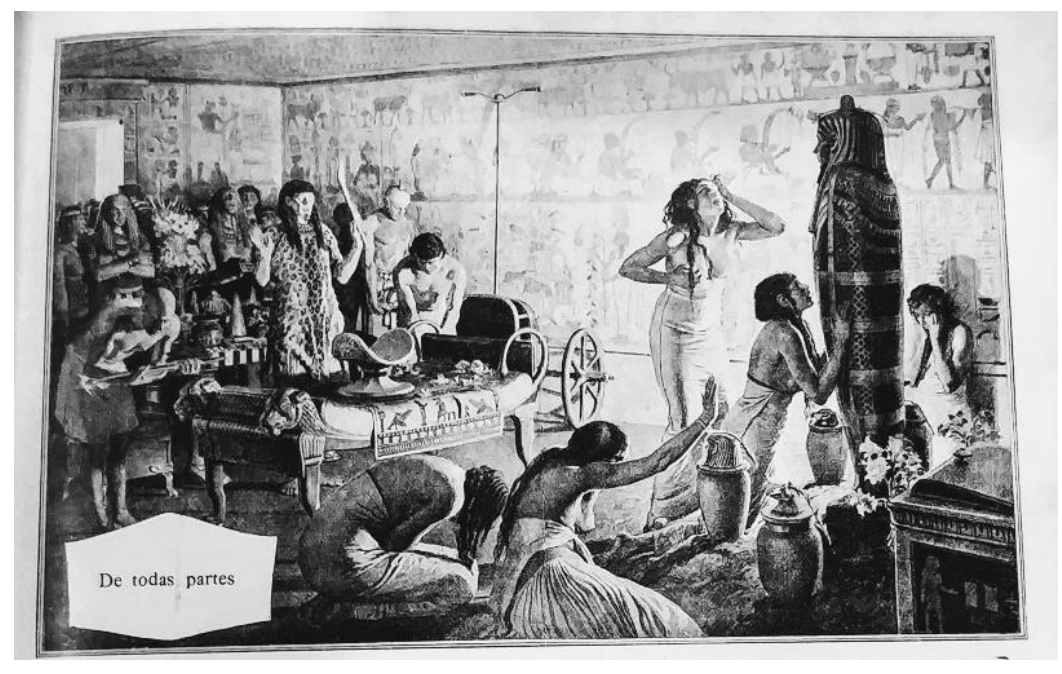

Fig. 5. De todas partes, Atlántida, 22/2/1923. Biblioteca Nacional Mariano Moreno

\footnotetext{
27 De todas partes, Atlántida, 22/2/1923; La moda de Tutankhamon, El Hogar, 27/4/1923; Una escena de hace treinta y dos siglos, Critica, 8/3/1923
} 
Que haya sido la misma ilustración puede deberse a ciertos límites propios de la prensa sudamericana: es posible que la circulación limitada de imágenes exprese los condicionamientos que tenían los diferentes medios al momento de poder brindar al lector porteño una conexión instantánea con el mundo. Caimari (2015) indica que hasta los primeros años del siglo XX convivieron en diferentes medios los cables informativos con la entrega de "paquetes" de noticias, que contenían imágenes y contenido que se repetiría en diarios y revistas. Probablemente sin buscarlo, este fue un factor determinante que abonó a una idea monumental e impúdica de la antigüedad egipcia al repetirse imágenes que presentaban los rituales antiguos como un espacio liminal entre la muerte y el goce, permitiendo pervivir los tintes eróticos victorianos de la figura de la momia.

Las cuotas de exotismo y sensualidad se dosificaron con elementos supersticiosos: la muerte, los secretos sepulcrales y el misticismo oriental también se hicieron presentes en la cobertura de los semanarios. Si el contenido de la cámara mortuoria fue mostrado con extremo detalle, las supersticiones y el miedo a los muertos también cobraron relevancia: un pequeño artículo contaba como la poetisa Madame Noailles, siguiendo los dictados de la moda, se mandó a hacer un traje estilo egipcio, pero la repentina muerte de Carnarvon hizo que se lo regale a una de sus mucamas, que al cabo de cinco días heredó una fortuna. ${ }^{28}$ La maldición de la momia se transformó en un tópico recurrente y fue reconvertida en "la maldición del faraón"29 o "la maldición de Osiris":30 sea quien sea el espíritu maldiciente, la fatídica muerte del Lord Carnarvon no era otra cosa que una profunda sanción a la apertura de tumbas, sugiriendo que el inglés tentó a la suerte y no respetó las fuerzas sobrenaturales, encontrando un destino fatal "en una aventura en la que no debió ver inicialmente más que una incidencia de turismo". Las críticas en tono moralizante no tardaron en aparecer y multiplicarse: desde El Hogar se preguntaban "hasta qué punto tenía un excavador (...) el derecho de violar esas tumbas", poniendo en cuestión si el "el carácter científico" permite la justificación de "el pillaje lúgubre a que dan pretexto"31. Este temor se extendió y hasta americanizó al compararlo con el saqueo de las huacas, centros ceremoniales y funerarios incaicos, por parte de los guaqueros, sus profanadores: la tragedia signa sus destinos al tener el "tremendo oficio" de profanar tumbas "un castigo inevitable". ${ }^{32}$

El clima de febril entusiasmo generado por Tutankhamón reactivó el interés por la figura de la momia, que por momentos maravillaba: de hecho, resultaba sumamente fascinante las diversas formas de embalsamiento descubiertas, detallándose las

\footnotetext{
28 Superstición, Atlántida, 5/7/1923.

29 La maldición de los dioses, El Hogar, 13/4/1923.

30 La maldición de Osiris, Caras y Caretas, 14/3/1925

${ }^{31}$ La maldición de los dioses, El Hogar, 13/4/1923.

32 El castigo de los profanadores de tumbas, Caras y Caretas, 22/9/1923.
}

\section{anuario.}


similitudes y diferencias entre los métodos $^{33}$ que permitían burlar el paso del tiempo, ya que la momificación detiene "la marcha de los siglos sobre la momias incólumes". 34

En plena fiebre egiptomaníaca apareció el "Lord Carnarvon argentino", Rafael Gentile, que descubrió un cuerpo en la puna de Atacama. Los periódicos aprovecharon el fervor egipcio y se adentraron en las particularidades de la momificación egipcia en contraposición al cuerpo encontrado, perteneciente en teoría a un rey incaico. Las comparaciones con las tumbas egipcias no tardaron en aparecer: los objetos desenterrados en Atacama "guardan una gran analogía con los que se hallaron en la tumba de Tut-Ankh-Amon", avisando de una próxima exposición al público, ya que "será exhibida dentro de algunos días en un local cedido al efecto en la calle Sarmiento y Callao". Eventualmente, Manuel Carlés, fundador de la Liga Patriótica, la exhibió en alguna reunión de la asociación: según Crítica, empalidece al lado de Tutankhamón, ya que es "feo y flaco, está verdaderamente en los huesos", aunque Carlés insistió que esa momia podrá otorgar un pasado épico y místico a la nación argentina. ${ }^{35}$ Las imágenes de esta momia nacional se alejan del lujo y la suntuosidad egipcia, pero permanecieron presentes las fantasias y las peculiaridades del mundo de la muerte no occidental.

La presencia de la figura de la momia no fue aislada ni accidental, y la recurrencia de Tutankhamón otorgó cierto sentido a otras momias que, a pesar de ser menos monumentales y menos cosmopolitas, se filiaron al halo de seducción y terror faraónico. En este orden, diarios y revistas se ocuparon de construir la percepción de magnanimidad del acontecimiento, presentando no solamente al faraón sino también el mundo del Antiguo Egipto a partir del lujo, el misterio y lo maravilloso, que por momentos se conjugó con la oscuridad y la muerte. Si los cables fueron una primera base de apoyo y se utilizaron ilustraciones extranjeras, la prensa local también generó contenido para llegar al lector porteño: de alguna manera, Tutankhamón no solamente hablaba de la antigüedad, sino también del mundo moderno, permitiendo comulgar al lector con la sensación de maravilla.

\footnotetext{
33 Momias egipcias, Caras y Caretas, 3/5/1924

34 En la tumba de Tutankhamón, Caras y Caretas, 2/4/1924.

35 Ha sido encontrada una momia 'argentina' cuya conservación es perfecta, Crítica, 18/5/1923; En el cerro Lincancao fue descubierta una momia, La Nación, 18/5/1923; El Tutankhamon argentino, Crítica, 9/6/1923. En Atlántida incluso aparecerá una nota satirizando el descubrimiento arqueológico. Veáse ¡A Apareció el cadáver de nuestro ex Director!!, Atlántida, 1/6/1923.
}

\section{anuario.}




\section{Lugones y la maldición de la momia}

Fue Leopoldo Lugones quien condensó el interés porteño en Tutankhamón en dos relatos que fueron publicados en 1923: "El vaso de alabastro" y "Los ojos de la reina". ${ }^{36}$ Estas dos narraciones formaron parte de una compilación publicada en 1924: Cuentos fatales.

La seducción, la muerte y el destino son tópicos presentes en las historias de la antología, pero es en las dos mencionada que se hará especial referencia al mundo egipcio, a la maldición de la momia y a los poderes místicos que guían el destino. En "El vaso de alabastro", Lugones presenta un erudito escocés de visita en Buenos Aires, Mr. Richard Neale. Hospedado en el Hotel Plaza, Mr. Neale se encontraba en el país para conversar con aquellas personas interesadas en los descubrimientos arqueológicos en Egipto. Él no solo era una persona culta e informada de la historia egipcia, sino que también había acompañado a Carter y Lord Carnarvon en la apertura de la tumba del faraón. Mantenía un secreto resguardado de la prensa mundial: lo que terminó con la vida de Carnarvón no fue otra cosa que el perfume de la muerte que se encontraba en un vaso de alabastro. Con este enigma oculto en su memoria y que comparte con el narrador, el horror paraliza a Mr. Neale cuando huele aquella poderosa fragancia en una mujer que se alojaba en su mismo hotel. Esta misteriosa mujer, llamada Sha-it, era casualmente de procedencia egipcia; poseedorá de una belleza impactante, en "El perfume de la reina" se develará que ella no es nada menos que la reencarnación de la reina Hatshepsut, cuya mirada es fatal: Mr. Neale se enamora de la increíble belleza de Sha-it, que termina siendo su inevitable final. Si el perfume era el peligro fantástico que escapa de la lógica científica en el primer relato, en el segundo ese lugar es ocupado por la mirada de belleza y muerte de Shatit; mirada que conocieron, primero, unos exploradores que encontraron un espejo en una excavación, y que les devolvió no un reflejo sino un semblante mortal "de más de tres mil años".

Es importante entender el lugar del Oriente en la obra de Lugones para dar cuenta de los elementos que atraviesan estas narraciones. Se ha señalado que, si bien los motivos orientalistas son marginales en sus escritos, se recurre a estos como un recurso principalmente estetizante (Gasquet, 2007, p. 211). Así, la suntuosa y tétrica tumba de Tutankhamón se encuentra llena de misterios; los objetos que se hallan ahí son fantásticos o de otro mundo, como aquel perfume que posee un aroma de una "cautividad de treinta siglos en una perpetuación casi inmortal"; Sha-it, por su parte, representa el terror y la belleza femenina prototípica del Oriente, dueña de un halo misterioso y regio. En la a mirada fatal de Sha-it puede verse un erotismo latente y peligroso, un arma femenina de seducción que, para los años veinte, se había transformado en un lugar común orientalista gracias a la figura de la vamp: una

${ }^{36}$ El vaso de alabastro, La Nación, 19/8/1923; Los ojos de la reina, La Nación, 28/9/1923.

\section{anuario.}


representación cinematográfica que tenía alcance global producto del apogeo del cine hollywoodense y que, gracias a los largometrajes, será vinculada con mujeres orientales, como Cleopatra o Salomé, cuya eximia sexualidad puede llevar a la decadencia moral y material a cualquier hombre. ${ }^{37}$ En este sentido, Shirley Longan Phillips (2013) ha señalado el poder cautivador del rostro de Sha-it como desencadenante de un juego de flirteo con resultados trágicos: la muerte de Mr. Neale (pp. 6-7).

En ambos relatos puede encontrarse una dualidad muy marcada, pues converge la oscuridad de la antigüedad egipcia con la cotidianeidad urbana de Buenos Aires. En "El vaso de alabastro", son dos los espacios en donde transcurre la historia de Mr. Neale: la tumba de Tutankhamón y el Hotel Plaza, en donde él se hospeda y entabla conversación con el narrador. En "Los ojos de la reina" se menciona el lugar de trabajo del fallecido Mr. Neale, el Ministerio de Obras Públicas, mientras que el narrador participa de un cortejo fúnebre de lo más tradicional, alejado de los rituales egipcios. Esta mixtura puede leerse como un esfuerzo de Lugones de hacer a Buenos Aires parte de ese mundo que se encontraba seducido por la egiptomanía, con la muerte del Mr. Neale en la capital argentina emulando la suerte de Carnarvon en El Cairo. De esta forma, la cotidianeidad porteña cobra aires inusualmente místicos.

Al mismo tiempo que un motivo estetizante, en el Oriente en Lugones también hay huellas de su pensamiento teosófico. Es dificil ignorar el interés del escritor en los elementos místicos que la esta doctrina populariza en el cambio de siglo y que el escritor los consideraba trascendentales. El Oriente teosófico es un repositorio de elementos mágicos, esotéricos y reveladores, que son esenciales en la búsqueda conocimiento y de la verdad superadora del materialismo. Este aspecto ha sido vehementemente señalado por Soledad Quereilhac (2015, pp. 203-220), para quien no existe una contraposición o separación en los tópicos de la obra lugoniana, en la cual confluyen experimentos científicos con anhelos esotéricos: el mundo de lo oculto se encuentra por encima del mundo de la ciencia positiva (p. 207). Tanto en el "El vaso de alabastro" como en "Los ojos de la reina" hay un elemento mítico que se encuentra por encima del raciocinio científico: aquel perfume mortal y aquella mirada fatal forman parte real de la antigüedad egipcia y, por ende, de la historia del mundo. Las victimas de estas fuerzas sobrehumanas actúan por impulsos o ignorancia (Carnarvon al oler el perfume, Mr. Neale al ser seducido por Sha-it), siendo castigados con la tragedia al transgredir principios irrevocables, vinculados a leyes universales

37 La figura vamp aparece mediados de los años diez y principios de los veinte e invaden la imaginación del mundo entero. La actriz Theda Bara fue iniciadora cuando protagonizó en 1915 el film A Fool There Was, en el cual personifica a una mujer que seducía y fascinaba a un padre de familia, para luego llevarlo a la decadencia absoluta. La mujer vamp conlleva el peligro de la sensualidad y sexualidad femenina. Una mirada fascinante y performances las antipodas de lo natural se amalgamaban con ropa lujosa, el exhibicionismo de las poses y magnificencia de las ceremonias. Véase la obra de Antonia Lant (1992) y De Baecque (2006). 


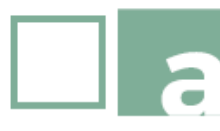

y primordiales (De Mora, 2000 [1995], pp. 37-83). Por otro lado, no es la primera vez que Lugones aborda la cuestión de la reencarnación, tema caro a la teosofia orientalista. ${ }^{38}$

Finalmente, ambos relatos pueden ser indicativos de cierta circulación del tema. La publicación de pequeñas narraciones en las páginas de diarios o semanarios no era atípica, sino todo lo contrario: formaba parte de los contenidos misceláneos a los cuales estaban acostumbrados los lectores desde finales del siglo XIX, cuando Caras y Caretas empieza a publicarse (Rogers, 2007). Especialmente hay indicios de una masivización de la tutmanía en "El vaso de alabastro": desde un principio, Mr. Neale teme ser tomado por un charlatán, ya que sabe "el descrédito en que han caído tales cosas"; en otro pasaje, el erudito se ahorra detalles en su descripción de la apertura de la tumba del faraón, pues sabe que esas son "cosas popularizadas, por lo demás en todos los magazines"; por último, el narrador le comenta a Mr. Neale que recuerda haber leído en algún lado, "con asombro", la fragancia vaga y distintiva que inundó el sepulcro real.

\section{Momias y faraones criollos}

Otro indicador del interés que generó Tutankhamón es la utilización de su figura para la sátira y el humor político. Es relevante la aparición del motivo faraónico en el humor gráfico, que es, como sostiene Florencia Levín (2015) "un tipo particular de discurso social que captura fragmentos de ideas, imágenes y opiniones" que circula en determinados espacios sociales y que la prensa masiva los pone a disposición de un heterogéneo público que "los transforma y los vuelve a lanzar a la circulación (...)", permitiendo el "flujo de las representaciones sociales" (p. 24). El humor gráfico no solamente recoge las percepciones que circulan en determinada sociedad, sino que presiona activamente sobre ellas para instituir imaginarios colectivos.

Momias y faraones aparecieron en viñetas cómicas de origen extranjero y nacional. La Nación publicaba en sus páginas Bringin'up father, una tira norteamericana que se hizo muy popular los años veinte, que el público argentino conoció como Pequeñas delicias de la vida conyugal. Los lectores podian divertirse con las situaciones cotidianas de una pareja de inmigrantes enriquecidos que intentan amoldarse a ciertos parámetros culturales, propios de sectores acomodados: Sisebuta, la esposa, es quien pugna por refinarse, esforzándose para que Trifón, su marido, abandone ciertas acciones y actitudes vulgares para abrazar el buen gusto y los modales. Fueron recurrentes los vestidos egipcianizados que lucía Sisebuta, que incluso

\footnotetext{
38 El tema de la reencarnación fue abordado por Lugones en "Ensayo de una cosmogonía en diez lecciones", en Las fuerzas extrañas.
}

\section{anuario.}


regañó en alguna ocasión a Trifón por ignorar totalmente quién había sido Tutankhamón. 39

Las versiones criollas de Sisebuta y Trifón fueron Petronila y Pancho Talero, que aparecieron dos años más tarde en las páginas de El Hogar, en la tira cómica titulada Las aventuras de Pancho Talero. De la pluma del dibujante Arturo Lanteri, esta tira cómica repite la fórmula en la cual la señora de casa busca civilizar a su marido para mostrarse como un matrimonio culto y moderno. Petronila y Pancho eran dos porteños y, como habitantes de la ciudad, podría resultar más cercanos que Sisebuta y Trifón para cualquier lector. Tal vez por este motivo, los guiños a la tutmanía que encontramos en esta historieta hablen mejor de como los vecinos de Buenos Aires vieron a la figura de Tutankhamon. Petronila, por ejemplo, se vistió para recibir el año nuevo con un vestido con motivos egipcianizados, tal vez como un símbolo de mujer con cierto gusto moderno. Incluso en una ocasión Pancho se molesta de sobremanera porque su esposa compra vestidos "tutankhamen" para ella, su hija Mechita y la criada Blanquita (fig. 6). Mientras Petronila lo trata de ignorante al no comprender sobre gustos refinados, Pancho la considera una crédula que sigue cualquier tontería de "moda". Pero decidido a que devuelvan los vestidos, resuelve jugarles un engaño: Pancho lleva un sarcófago y se hace pasar por una momia que asusta a las incautas mujeres por ridiculizar su cultura, que terminan pidiéndole perdón a la momia "Ta-te-ti". 40

\footnotetext{
39 Pequeñas delicias de la vida conyugal, La Nación, 31/5/1923. Puede verse a Sisebuta vistiendo ropajes egipcianizados en las entregas de La Nación, 24/5/1923; y La Nación, 2/6/1923

40 Las aventuras de Don Pancho Talero, El Hogar 27/4/1923. Sisebuta luce su vestido faraónico en la publicación del 28/12/1923. Para un análisis sobre las marcas de género que se presentan las historietas mencionadas, véase Gené (2012).
} 


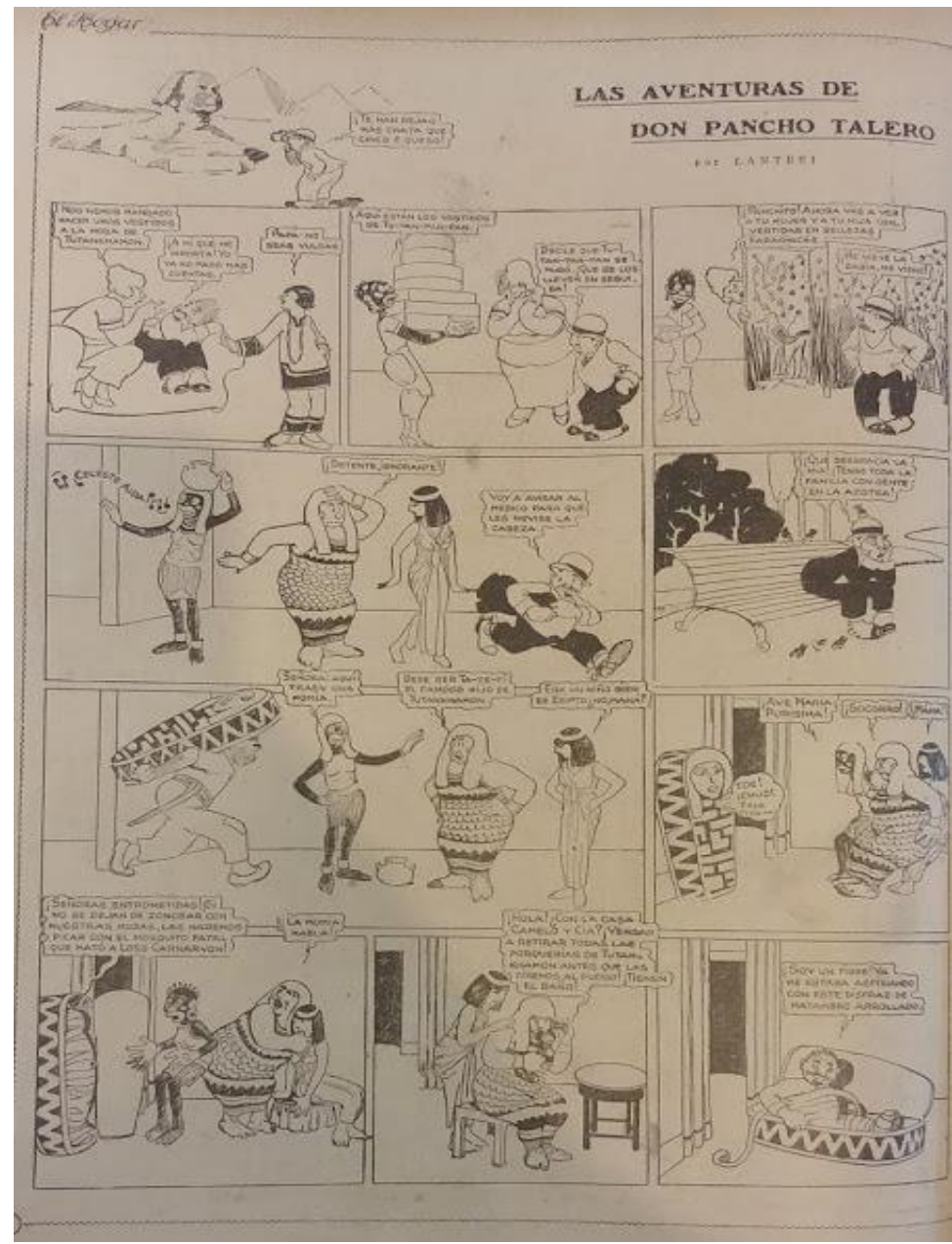

Fig. 6. Las aventuras de Don Pancho Talero. El Hogar, 27/4/1923. Biblioteca Nacional Mariano Moreno

El primer personaje de la historieta argentina, Don Goyo Sarrasqueta y Obes, también se hará eco de la tutmanía. Creado en 1913 por el dibujante Manuel Redondo, Sarrasqueta es un migrante español en una continua búsqueda de un lugar en una Buenos Aires que cambiaba a pasos agigantados. Como sugieren Judith Gociol y Diego Rosemberg (2000), Sarrasqueta se encontraba siempre atento a la actualidad y muy compenetrado con los temas nacionales, siendo la ciudad no solamente el escenario de sus andanzas sino parte de su crítica. Es así que imitando a un arqueólogo, en sintonía con la popularidad de esta disciplina en los años veinte (Peralta, 2016, pp. 185-222), Sarrasqueta muestra su museo con las nuevas antigüedades, entre las cuales se encontraba el refinado vaso de Tutankhamón con su "canuto hueco", aunque no era otra cosa que un mate con su bombilla que se podía obstruir como a cualquier habitante de Buenos Aires. ${ }^{41}$

${ }^{41}$ El museo de Sarrasqueta, Caras y Caretas, 20/10/1923. 
$\overline{\text { Dentro de las figuras satíricas, la momia fue también utilizada como }}$ un signo político. Ya ha sido señalado por Silvana Palermo y Sandra Gayol (2017, pp. 13-27) que la política y la cultura de masas se influenciaron mutuamente, ya que los productos masivos pueden ser parte de la "arena de politización", más allá de que sean consumidos por sectores que no participen de la esfera política formal. En este sentido, tanto la figura faraónica como el motivo de la tumba fueron utilizados para hacer referencia a la situación política nacional. Desde 1922, la Unión Cívica Radical, partido gobernante, se enfrenta a conflictos internos que cobran notoriedad pública. El motivo aparente se víncula a la tensión entre Hipólito Yrigoyen, presidente de la nación entre 1916 y 1922, y Marcelo de Alvear, primer mandatario entre 1922 y 1928.

Las facciones partidarias se multiplican, y el conflicto principal es demostrar quién tiene el poder en verdad: Yrigoyen había amasado una enorme cantidad de simpatizantes, que lo erigieron como una sacra autoridad y le imprimían al radicalismo un tono sensual, agresivo y sectario (Carrera, 1980, pp. 174-175); mientras tanto, otros miembros del partido lo veían como un perturbador de los principios orgánicos del radicalismo, como un "accidente funesto" que busca eternizarse en el poder (Persello, 2003, p. 64). La división estaba clara entre personalistas, partidarios de Yrigoyen, y antipersonalistas, partidarios de Alvear. En el cambio de gobierno de 1922, la prensa saluda al nuevo presidente como producto legítimo de una "reacción democrática" contra el anterior gobierno (Persello, 2003, p. 110). Pero para las elecciones de 1924, la lucha facciosa no se detiene en lo absoluto, y la prensa se extasía en ello.

Fueron dos dirigentes politicos los principales objetivos de las comparaciones con el faraón: Elpidio González e Hipólito Yrigoyen. El expesidente es presentados por momentos como autoritario y hasta despótico, casi como una farsa histórica que ocultaba sus intenciones para engañar a las masas y mantener su caudal electoral, siendo el representante de un retorno a la barbarie (Piñeiro, 2006, p. 122). En una de sus viñetas, Sarrasqueta se suma a las críticas contra Yrigoyen al compararlo con Tutankhamón: al parecer, en su tumba se encontró la mano de una momia que sostenía un bastón presidencial y no quería soltarlo, "como muchos presidentes". ${ }^{4}$ Tal vez entendido el poder faraónico como total y eterno, el tópico del despotismo oriental parece reformularse para generar una crítica democrática.

El uso del motivo egipcio para criticar a Yrigoyen no es nuevo, pero se ve revigorizado y multiplicado en medio de la tutmanía. Ya en marzo de 1920, las portadas de Caras $y$ Caretas usaron la figura de la esfinge con el rostro de Yrigoyen y una urna electoral, intentando mostrar lo anacrónico que es un faraón en el medio de un sistema democrático; ${ }^{43}$ cuatro años más tarde, en mayo de 1924, el semanario mostró en su

42 Sarrasqueta no aguanta latas, Caras y Caretas, 29/12/1923.

43 Las portadas son las de Caras y Caretas, 6/3/1920; y Caras y Caretas, 27/3/1920

\section{anuario.}




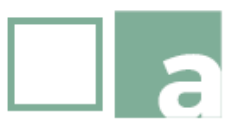

portada una satira del exmandatario, ataviado con ropajes egipcios y acompañado con un ave que simulaba ser el halcón Horus, pero con el rostro del vicepresidente Elpidio González (fig. 7). La situación en ambos períodos es diferente: en 1924, era Marcelo de Alvear el primer mandatario, y el vicepresidente era González, al que la prensa señalaba como un ladero que respondía ciegamente al ex primer mandatario. El faraónico Yrigoyen tenía una sartén por el mango en una mano y la urna de votos de Buenos Aires en la otra: en ese año se realizaron elecciones legislativas, que demostraron el apoyo popular que tenía Alvear. La imagen tal vez haga referencia a la perdida de apoyo del expresidente, aunque dando a entender que ninguna manera se retiraría de la arena política. Los jeroglíficos ilegibles no eran otra cosa que artículos cotidianos de la vida porteña, como cuchillos, mates, empanadas o chorizos, que podían significar, según uno de los hombres que contemplaban la imagen, "no está muerto quien pelea". ${ }^{44}$ La utilización de estos objetos de uso común, en función a la urna de votos, también puede estar estrechamente relacionado con la filiación popular que muchos opositores achacaban al radicalismo y, especialmente, a Yrigoyen. El vicepresidente Gonzáles fue otro blanco central de las críticas. Hombre de confianza de Yrigoyen, era visto como la mano invisible del expresidente radical para limitar el poder del jefe de Estado (Piñeiro, 2006, pp. 129-130). En una carta, un caricaturizado González le pedía al faraón Alvear los atributos presidenciales: "espero el bastón, mándeme la banda. Apúrese Marcelo",45 acompañado por otros personajes de la política argentina egipcianizados (fig. 8). Un año más tarde, se disfrazaría de Tutankhamón para los carnavales de 1924, demostrando su ambición personal de suplantar al presidente y su actitud antirepublicana.

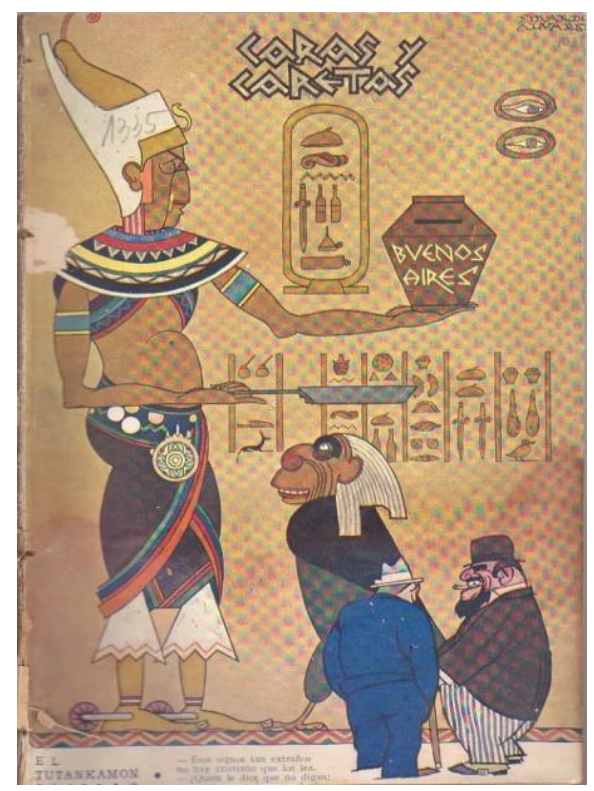

Fig. 7. El Tutankhamon criollo. Caras y Caretas, 3/5/1924. Biblioteca Nacional Mariano Moreno.

44 El Tutankhamon criollo, Caras y Caretas, 3/5/1924

${ }^{45}$ La carta de Elpidio, Caras y Caretas, 14/4/1923 


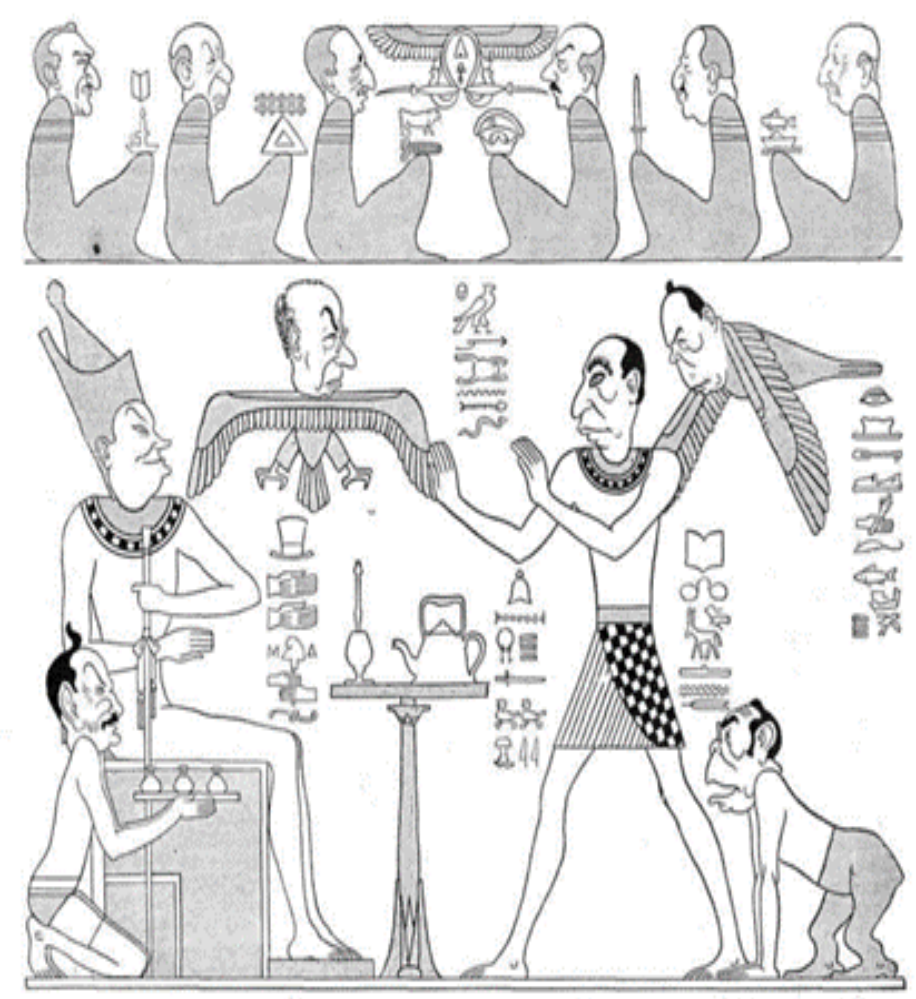

Fig. 8. La carta de Elpidio. Caras y Careta, 14/4/1923. Biblioteca Nacional Mariano Moreno

El semanario Atlántida hizo alusiones con motivos egipcios para atacar el funcionamiento del Senado, ya sea utilizando la figura del "Tutankhamón criollo" o representando al Congreso como un sepulcro de momias ${ }^{46}$ en relación a la inercia parlamentaria, metida de lleno en las tensiones entre personalistas y antipersonalistas que incluso llegó a despojar al vicepresidente González de la facultad de nombrar miembros de las comisiones (Piñeiro, 2006, p. 131). El frontispicio de una edición mostraba dos mujeres que representaban a Jujuy y Córdoba, provincias que irian a ser intervenidas por el poder ejecutivo, con la leyenda "hay para rato"47 (fig. 9). Ambas señoritas estaban vestidas con ropajes clásicos, con una probable referencia republicana y en contraposición al sarcófago faraónico, que representaba los oscuros manejos del Senado. Las intervenciones federales de estas dos provincias fueron tomadas como un signo de la voluntad antidemocrática del radicalismo personalista. Jujuy recién será intervenida hacia fines de 1923, pero la intervención de Córdoba resultará fallida: había sido sancionada en la Cámara de Diputados ya en octubre de 1922, pero finalmente será rechazada recién en julio de 1924 (Piñeiro, 2006, pp. 131-136). Ya se había señalado que el tópico de la

\footnotetext{
46 Los frontispicios alusivos son respectivamente los de Atlántida, 1/3/1923; y Atlántida, 14/6/1923.

47 Frontispicio, Atlántida, 14/6/1923.
} 
perennidad milenaria de la tumba de Tutankhamón había sido retomado virtualmente por casi toda la prensa, motivo por el cual no resulta descabellado suponer que se utilizó un tema que circuló entre los diferentes sectores sociales para criticar al poder político.

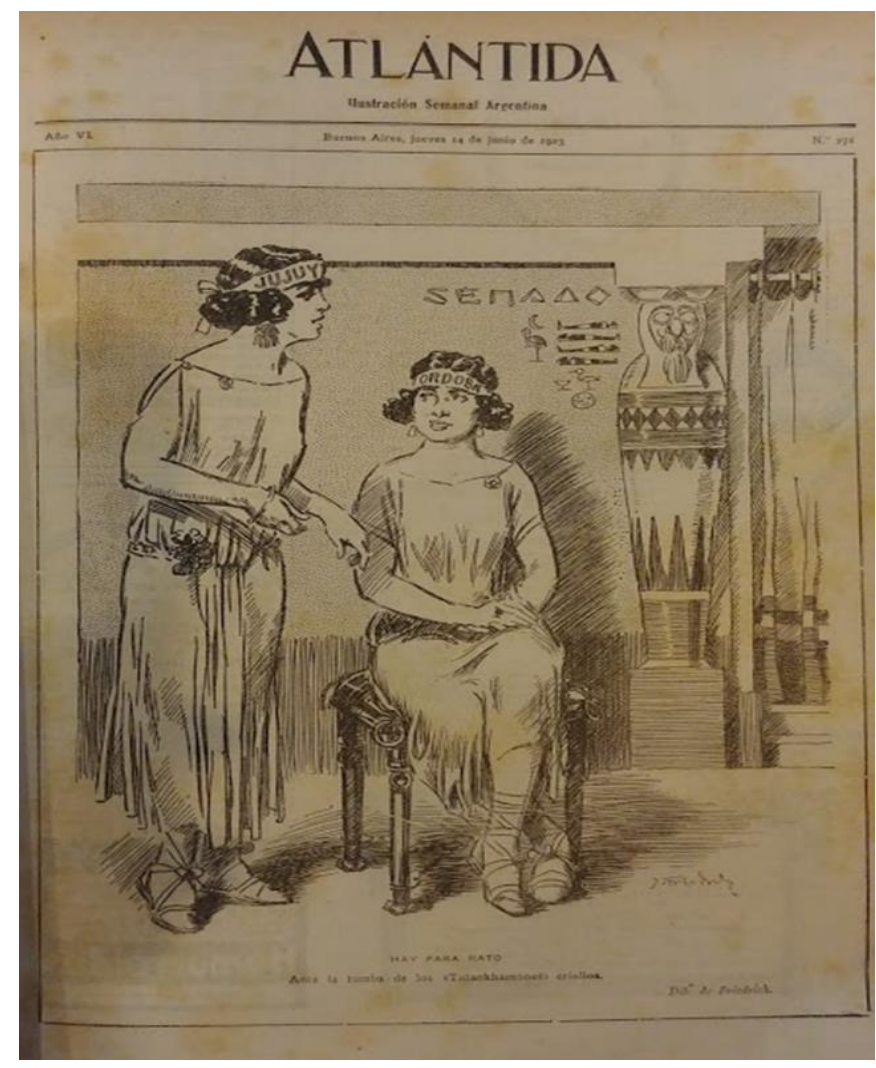

Fig. 9. Frontispicio. Atlántida, 14/6/1923. Biblioteca Nacional Mariano Moreno

\section{Conclusiones}

Hacia los primeros años veinte, los habitantes de Buenos Aires pudieron sentir parte de esa fascinación que invadió al mundo entero. El descubrimiento de la tumba de Tutankhamón hizo que el Antiguo Egipto sea un tema cotidiano: las imágenes mostraban al rey en su esplendor, mientras el misterioso poder sobrenatural y la maldición del faraón permitiría cargar de misticismo a esta sociedad.

Es cierto que gran parte de este contenido era de precedencia extranjera y se repetía a través de diferentes publicaciones, evocando un sugerente y místico universo perdido a partir de artículos en los periódicos, cables, notas de actualidad, cuentos e ilustraciones. Pero la prensa vernácula no se limitó a reproducir el material extranjero, sino que buscó filiar a la sociedad porteña con el novedoso mundo de Tutankhamón. Así, se buscó darle un tono vernáculo al tema, llegando a publicitar una momia argentina. 
$\overline{\text { La producción de este contenido a escala más local permitió vincular a }}$ esta sociedad extraeuropea con el horizonte global. Así, un lector no solamente podría seguir de forma métodico el devenir del descubrimiento y sus huellas en Europa, sino que el Antiguo Egipto se hará presente cuando Leopoldo Lugones traslade ficcionalmente la magia egipcia a las calles de Buenos Aires, o cuando los diarios y revistas utilicen la figura del faraón Tutankamón para criticar la feroz interna del partido gobernante. El enorme interés que despertó la figura de Tutankhamón puede entenderse como la expresión del afán cosmopolita de una sociedad que, hacia los años veinte, distaba mucho de ser un pequeño conglomerado urbano decimonónico. Es que la tutmanía fue un nexo que permitió a la sociedad porteña formar parte de un horizonte global, apropiándose de Tutankamón

Hacia 1925, la presencia del faraón empieza a discontinuarse: seguirá apareciendo material referido a él o a la cultura egipcia, pero con menos fuerza e intensidad. La tutmanía había perdido su potencia, aunque sin desaparecer: periódicos como Crítica, La Nación y La Razón seguirán esporádicamente informando a sus lectores sobre las novedades arqueológicas y el estudio científico de la tumba de Tutankhamón (Peralta, 2016, pp. 185-222). Como Méndez y Belej (2012) lo han señalado, mausoleos del Cementerio de Recoleta fueron ornamentados con motivos egipcianizantes, o refaccionados o construidos hasta finales de la década de 1920, dejando en evidencia que Egipto seguía formando parte, por lo menos, del gusto de la élite. Un detalle de estos mausoleos es que las referencias al Antiguo Egipto desbordan ampliamente las imágenes que circularon la prensa durante la tutmanía: amuletos de faraones, diosas poco conocidas y símbolos culticos pueden ser indicativos que Tutankhamón efectivamente fue un signo popular y democratizante al cual los miembros de la elite hacen poca referencia.

Aunque parte de un pasado casi mítico, el Antiguo Egipto y Tutankhamón, se transformaron en la novedad para las y los porteños de los años veinte. La vida urbana y el progreso científico no fueron tópicos irreconciliables con esta antigüedad sensual y misteriosa, sino la base en donde se apoyó la tutmanía, que pudo hacer resurgir un tiempo y espacio que permitió a los modernos lectores y consumidores urbanos alejarse del presente.

\section{Bibliografia}

Altamirano, Carlos (1994). El orientalismo y el despotismo en Facundo. Boletín del Instituto de Historia Argentina y Americana "Dr. Emilio Ravignani". Tercera serie 9, 7-19. 


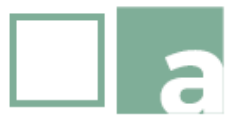

El encanto de Tutankhamón. La egiptomania en la prensa porteña (1923-1925)

Ariza, J. (2017). Imagen impresa e historia de las mujeres. Representaciones femeninas en la prensa periódica ilustrada de Buenos Aires a comienzos del siglo XX (1910-1930). (Tesis de Doctorado inédita). UBA, Buenos Aires.

Assmann, J. (2005). El lugar de Egipto en la historia de la memoria de Occidente. En G. Schröder. y H. Breuninger. (Comps.), Teoría de la cultura (pp. 54-74.). Buenos Aires: Fondo de Cultura Económica.

Bakos, M. (2004). Egyptomania. O Egito no Brasil. San Pablo: Paris Editorial.

Bakos, M., Santos, M., Coelho, L., y da Silva, G. (2012). História da Egiptomania no Brasil: Bibliografia Comentada. Plêthos 2 (1), 218-246

Belej, C., y Méndez, M. (2011). Lotos, papiros y esfinges. La influencia egipcianizante en la arquitectura funeraria del Cementerio de la Recoleta. Claroscuro. Revista del Centro de Estudios sobre Diversidad Cultural X (10), 1335.

Bergel, M. (2015). El Oriente desplazado. Los intelectuales y los orígenes del tercermundismo en Argentina. Buenos Aires: Universidad Nacional de Quilmes Editorial.

Bontempo, P. (2012). Editorial Atlántida. Un continente de publicaciones, 19181936. (Tesis de Doctorado inédita). UdeSa, Buenos Aires.

Caimari, L. (2015). El mundo al instante. Noticias y temporalidades en la era del cable submarino. Redes 21 (40), 125-146.

Caimari, L. (2018). En el mundo-barrio. Circulación de noticias y expansión informativa en los diarios porteños del siglo XIX. Boletin del Instituto de Historia Argentina y Americana "Dr. Emilio Ravignani" 49, 81-116. Recuperado de http://ppct.caicyt.gov.ar/index.php/ravignani/article/view/13479/pdf_1

Carter, H., y Mace, A. (1963 [1923]). The Tomb of Tut-Ankhamen (3 vols). Nueva York: Cooper Square Publishers.

Cohen, J. (1996). Monster Theory. Reading Culture. Mineápolis: University of Minnesota Press.

Curl, J. S. (2005). The Egyptian Revival: Ancient Egypt as the inspiration for Design Motifs in the West. Nueva York: Routledge.

Day, J. (2006). The Mummy's Curse. Mummymania in the English-speaking world. Londres-Nueva York: Routledge. 
De Baecque, A. (2006). Pantallas. El cuerpo en el cine. En J. J. Courtine (Dir.), Historia del Cuerpo. Volumen 3. Las mutaciones de la mirada en el siglo XX (pp. 359-400). Madrid: Taurus.

De Mora, C. (2000 [1995]). En breve. Estudios sobre el cuento hispanoamericano contemporáneo. Sevilla: Secretariado de Publicaciones de la Universidad de Sevilla.

Fritze, R. (2016). Egyptomania. A History of Fascination, Obsession and Fantasy. Londres: Reaktion Books.

Fryxell, A. (2017). Tutankhamen, Egyptomania, and Temporal Enchantment in Interwar Britain. Twentieth Century British History 28 (4), 516-542.

Gasquet, A. (2007). Oriente al sur. El orientalismo literario argentino de Estebán Echeverria a Roberto Arlt. Buenos Aires: Eudeba.

Gasquet, A. (2015). El llamado de Oriente. Historia cultural del orientalismo argentino (1900-1950). Buenos Aires: Eudeba.

Gayol, S., y Palermo, S. (2017). Política de masas y cultura de masas: recorridos y convergencias. En S. Gayol y S. Palermo (Comps.), Politica y cultura de masas en la Argentina de la primera mitad del siglo XX (pp. 13-27). Los Polvorines: Universidad Nacional de General Sarmiento.

Gené, M. (2012). "Sisebutas" en Buenos Aires. Family strips de los años veinte. Antiteses 5 (9), 181-204.

Gené, M., y Malosetti Costa, L. (Comps.) (2009). Impresiones porteñas. Imágen y palabra y la historia cultural de Buenos Aires. Buenos Aires: Edhasa.

Gené, M., y Szir, S. (Comps.) (2018). A vuelta de página. Usos del impreso ilustrado en Buenos Aires (siglos XIX y XX). Buenos Aires: Edhasa.

Gociol, J., y Rosemberg, D. (2000). La historieta argentina. Una historia. Buenos Aires: De la Flor.

Goldgel, V. (2013). Cuando lo nuevo conquistó América. Prensa, moda y literatura en el siglo XIX. Buenos Aires: Siglo XXI, 2013.

Gómez Espelosín, F., y Pérez Largacha, A. (1997). Egiptomanía. Madrid: Alianza.

Iñigo Carrera, H. (1980). La experiencia radical (1916-1922) (T.I). Buenos Aires: De la Bastilla. 


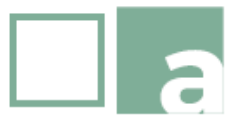
(1923-1925)

Jardines del Cueto, L. (2016). La problemática orientalista en el modernismo hispanoamericano: José Martí. Contra Relatos desde el Sur 13, 89-98.

Joyce, R. (2002). The Lan guage of Archaeology. New York: Blackwell.

Lant, A. (1992). The Curse of the Pharaoh, or How Cinema Contracted Egyptomania. October 59, 86-112.

Levín, F. (2015). Humor gráfico. Manual de uso para la historia. Los Polvorines: Universidad Nacional de General Sarmiento.

Longan Phillips, S. (2013). La mirada en "Los ojos de la reina" de Leopoldo Lugones: una lectura en fragmentos, Revista Humanidades 3, 1-10.

Luckhurst, R. (2012). The Mummy's Curse: The True History of a Dark Fantasy. Oxford: Oxford University Press.

MacDonald, S., y Rice, M. (2003). Introduction- Tea with a Mummy: the Consumer's View of Egypt's Immemorial Appeal. En S. MacDonald y M. Rice (Eds.), Consuming Ancient Egypt (pp. 1-22). California: Left Coast Press.

Marin, L. (2009). Poder, representación, imagen. Prismas. Revista de historia intelectual 13, 135-154.

Míguez, L., Malerba, M., y Flores, O. (2014). Bóvedas egipcíacas: análisis comparativo en las necrópolis de la Recoleta, La Plata y San Salvador de Jujuy. En C. Onaha y L. Rodríguez de la Vega (Comps.), Colección ALADAA documento 4. Congreso Nacional de ALADAA, 2014 (pp. 1204-1216). La Plata: ALADAA.

Moshenka, G. (2014). Unrolling Egyptian mummies innineteenth-century Britain. The British Journal for the History of Science, 1-27.

Nagy Zekmi, S. (Ed.) (2006). Paradoxical Citizenship. Edward Said. Maryland: Lexington Book.

Nagy Zekmy, S. (Ed) (2008). Moros en la costa. Orientalismo en Latinoamérica. Madrid: Iberoamericana.

Parramore, L. (2008). Reading the Sphinx Ancient Egypt in Nineteenth-Century Literary Culture. Nueva York: Palgrave Macmillan.

Peralta, D. (2016). La ciencia y "La Razón": la divulgación e información sobre ciencia en un diario de circulación masiva en perspectiva histórica (1917-1930). (Tesis de Doctorado inédita). UBA, Buenos Aires.

Persello, A. V. (2003). El partido radical: Gobierno y oposición, 1916-1943. (Tesis 
de Doctorado inédita). UBA, Buenos Aires.

Piñeiro, E. (2006). Las disidencias radicales durante la presidencia de Alvear. En A. David Leiva (Coord.), Los dias de Marcelo T. Alvear (T. II, pp. 119- 146). San Isidro: Academia Provincial de Ciencias y Artes de San Isidro.

Pons Mellado, E. (1999). El descubrimiento de la tumba de Tutankhamón: las visitas de H. Carter a España. ISIMU 2, 425-447.

Quereilhac, S. (2016). Cuando la ciencia despertaba fantasias. Prensa, literatura y ocultismo en la Argentina de entresiglos. Buenos Aires: Siglo XXI.

Rogers, G. (2007). Caras y Caretas: cultura, politica y espectáculo en los inicios del siglo XX argentino. La Plata: EDULP.

Rogers, G. (2014). 'Algo que decirle a la humanidad' en diarios y revistas: autores populares en la Argentina de 1920. En H. Ehrlicher y N. Rißle-Pipka (Eds.), Almacenes de un tiempo en fuga: Revistas culturales en la modernidad hispánica. Aachen: Shaker Verlag. Recuperado de https://www.revistasculturales.de/es/buchseite/geraldine-rogers-\%E2\%80\%98algo-que-decirle-lahumanidad\%E2\%80\%99-en-diarios-y-revistas-autores-populares

Said, E. (2002 [1978]) Orientalismo. Buenos Aires: De Bolsillo.

Saitta, S. (1998). Regueros de tinta. El diario Crítica en la década de 1920. Buenos Aires: Editorial Sudamericana.

Saitta, S. (2000). El periodismo popular en los años veinte. En R. Falcón (Dir.), Nueva Historia Argentina. Toma VI. Democracia, conflicto social y renovación de ideas (1916-1930) (pp. 435-471). Buenos Aires: Sudamericana.

Salem, L. (2018). El orientalismo en tensión. Lecturas sobre Egipto en los relatos de viaje a finales del siglo XIX en Argentina. Revista de Historia Americana y Argentina 53 (2), 39-81.

Saler, M. (2006). Modernity and Enchantment: A Historiographical Review. The American Historical Review 111 (3), 692-716.

Saler, M. (2012) As If: Modern Enchantment and the Literary Prehistory of Virtual Reality. Oxford

Saler, M., y Landy, J. (2009). Introduction: The Varieties of Modern Enchantment. En M. Saler y J. Landy (Ed.), The Re-Enchantment of the World: 


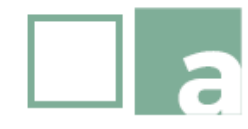

El encanto de Tutankhamón. La egiptomania en la prensa porteña (1923-1925)

Secular Magic in a Rational Age (pp. 1-19). Stanford, CA: Stanford University Press.

San Martín, J., y Serrano, J. M. (1998). Historia Antigua del Próximo Oriente. Mesopotamia y Egipto. Madrid: Akal.

Sánchez, E. (2014). Guerra de palabras. Representaciones, debates y alineamientos de la prensa y la opinión pública de Buenos Aires ante la Gran Guerra (1914-1919). (Tesis de Doctorado inédita). UBA, Buenos Aires.

Sarlo, B. (1997 [1992]). La imaginación técnica. Sueños modernos de la cultura argentina. Buenos Aires: Nueva Visión.

Sarlo, B. (2003 [1988]). Una modernidad periférica. Buenos Aires, 1920-1930. Buenos Aires: Nueva Visión.

Sarlo, B. (2011 [1985]). El imperio de los sentimientos. Narraciones de circulación periódica en la Argentina. Buenos Aires: Siglo XXI

Szir, S. (2011). El semanario popular ilustrado Caras y Caretas y las transformaciones del paisaje cultural de la modernidad. Buenos Aires 18981908. (Tesis de Doctorado inédita). UBA, Buenos Aires.

Taboada, H. (1998). Un orientalismo periférico: viajeros latinoamericanos (17861920). Estudios de Asia y África, 106, XXXIII (2) (pp. 285-305).

Tinajero, A. (2003). Orientalismo en el modernismo hispanoamericano. Indiana: Purdue University Press.

Wheatcroft, A. (2003). 'Wonderful Things': Publishing Egypt in Word and Image. En S. MacDonald y M. Rice (Eds.), Consuming Ancient Egypt (pp. 151-164). California: Left Coast Press.

Recibido: 30 de octubre de 2020 Aceptado: 15 de noviembre de 2020 Versión Final: 26 de noviembre de 2020 